\title{
Tourism carrying capacity assessment and environment: the case of Crete
}

\author{
B. S. Tselentis ${ }^{1}$, D. G. Prokopiou ${ }^{1}$, Em. Gyalirakis ${ }^{2}$ \& D. Bouga ${ }^{3}$ \\ ${ }^{1}$ Department of Maritime Studies, University of Piraeus, Greece \\ ${ }^{2}$ Land Surveyor, Rural Planner-Engineer, Greece \\ ${ }^{3}$ KOM 37-Architects, Greece
}

\begin{abstract}
Crete is the largest island in Greece. It covers an area of 8,303 sq. $\mathrm{km}$ and has $170 \mathrm{~km}$ of beaches. Tourism supply in Crete includes more than 200,000 beds which serve more than 3.5 million international tourist arrivals per year.

Cretan environment, both natural and manmade, can sustain a polymorphic tourism product for the island. The physical and cultural environment consist of an extended coastline with many sandy beaches, picturesque cities and traditional villages, unique mountains, wetlands and lakes.

The environment plays a vital role for the sustainable development of the tourism industry and offers a unique tourist product for the island.

The objective of this paper is to evaluate the impact of tourism and other economic activities on the environment of Crete and to estimate the quality of tourism products and services offered by the island's infrastructure.

In our study we have used environmental and tourism indices to estimate the impact of tourism and other businesses in the environment of Crete, in an attempt to address the challenges and options, pertinent to formulate a novel sustainable tourist development proposal.

Keywords: tourism carrying capacity assessment, carrying capacity in tourism, study for tourism in Crete, Crete tourism and environment, tourism and environment.
\end{abstract}

\section{Introduction}

The World Tourism Organisation (WTO) proposes the following definition of carrying capacity: "The maximum number of people that may visit a tourist 
destination at the same time, without causing destruction to the physical, economic, socio-cultural environment and an unacceptable decrease in the quality of visitors' satisfaction" [1]. For the Greek Islands, environment, both natural and manmade, plays a vital role for the sustainable development of the industry

Today, controlling tourist growth has become a central policy issue for the tourist trade [2], and it is noteworthy that carrying capacity assessment has become an important tool for facilitating planning and developing policy issues for the industry [3]. The purpose of this paper is to try and attain values for these indicators and integrate them into the planning process of the Greek tourist business [4].

Crete is the largest island of Greece and the fifth largest in the Mediterranean after Sicily, Sardinia, Cyprus and Corsica. It has an area of 8.162 square miles. Crete is the largest of the Greek islands, a long $260 \mathrm{~km}$ stretch with a width varying from $12 \mathrm{~km}$ to $60 \mathrm{~km}$ in its central part. It lies on the south of the Aegean Sea and its southern coast is on the Libyan Sea. Crete, with a population of 650,000 in year 2005, is one of the 13 regions into which Greece is divided. It forms the largest island in Greece and the second largest (after Cyprus) in the eastern Mediterranean. The island has an elongated shape: it spans $260 \mathrm{~km}$ (160 $\mathrm{mi})$ from east to west, is $60 \mathrm{~km}(37 \mathrm{mi})$ at its widest point, and narrows to as little as $12 \mathrm{~km}(7.5 \mathrm{mi})$ (close to Ierapetra). Crete covers an area of $8,336 \mathrm{~km}^{2}$ $(3,219 \mathrm{sq} \mathrm{mi})$, with a coastline of $1,046 \mathrm{~km}(650 \mathrm{mi})$; to the north, it broaches the Sea of Crete to the south, the Libyan Sea; in the west, the Myrtoan Sea, and toward the east, the Karpathion Sea. It lies approximately $160 \mathrm{~km}$ (99 mi) south of the Greek mainland [5].

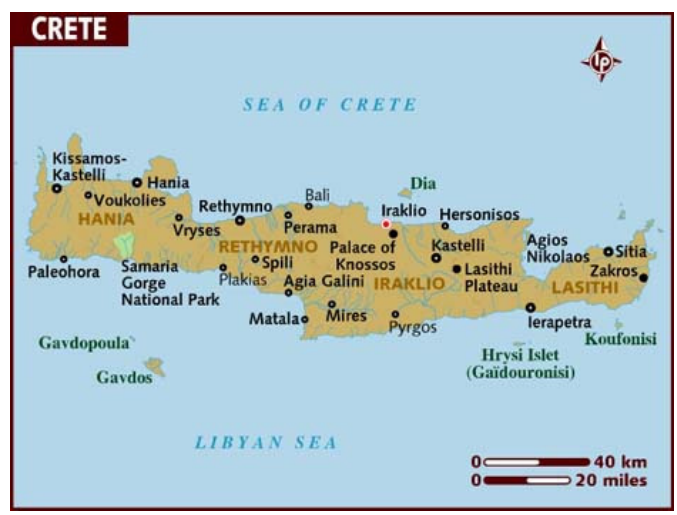

Figure 1: $\quad$ Map 1: Crete [6].

Crete has a unique tourist product that combines human and the natural environment, as tourism is an activity which cuts across conventional sectors in the economy. It requires inputs of an economic, social, cultural and environmental nature. 


\section{Population}

The population of Crete is mainly concentrated in the six large towns of the island, to the capitals of the four prefectures, Chania, Iraklion, Agios Nickolaos and Rethymno and also to Ierapetra and Sitia. As far as the education is concerned, there are two universities and one polytechnic school which gather students from all over Greece. We must also point out the fact that in Crete region, there is also a factory blooming industries. The population of Crete is employed in trade, handicrafts, tourism and agricultural economy, like farming and live stock rising. Cretans who either live in the cities or the villages, all maintain the time honoured customs and manners of their tradition. Cretan traditional music and Cretan cuisine are defining their uniqueness.

Crete has the highest population growth in Greece, increasing by approximately $20 \%$.

Table 1: $\quad$ Population history in Crete.

\begin{tabular}{|l|l|l|l|l|l|}
\hline & Heraclion & Lasithi & Rethimno & Chania & Crete \\
\hline 1981 & 243,622 & 70,053 & 62,634 & 125,856 & 502,165 \\
\hline 2001 & 292,489 & 76,319 & 81,936 & 50,387 & 601,131 \\
\hline Growth \% & 20.1 & 8.9 & 30.8 & 19.5 & 19.7 \\
\hline
\end{tabular}

\section{Ports and airports}

Crete gathers more than 4 million tourists per year. There are many ways to reach Crete. One can get there by plane or by boat.

Ports: In Crete, there are six ports that connect Crete with the other islands and the mainland of Greece, in Heraklion, Chania, Agios Nickolaos, Kasteli Kissamou, Rethymnon and Sitia. These ports are connected with continental Greece as to some Greek islands.

Airports: Three airports are operating in Crete. Two of them are international (Heraklion and Chania) and one is national (Sitia). Thousands of charters flights

Table 2: $\quad$ Arrivals in Cretan Airports.

\begin{tabular}{|r|r|r|r|r|r|r|}
\hline \multicolumn{7}{|c|}{ ARRIVALS IN CRETAN AIRPORTS } \\
\hline & $\begin{array}{r}\text { Chania International } \\
\text { Airport }\end{array}$ & $\begin{array}{c}\text { Heraclion International } \\
\text { Airport }\end{array}$ & $\begin{array}{c}\text { Sitia } \\
\text { Airport }\end{array}$ & $\begin{array}{c}\text { Total for } \\
\text { Crete }\end{array}$ \\
\hline & $\begin{array}{c}\text { Arrivals - } \\
\text { Domestic }\end{array}$ & $\begin{array}{c}\text { Arrivals } \\
\text { Abroad }\end{array}$ & $\begin{array}{c}\text { Arrivals - } \\
\text { Domestic }\end{array}$ & $\begin{array}{c}\text { Arrivals } \\
\text { Abroad }\end{array}$ & $\begin{array}{c}\text { Arrivals - } \\
\text { Greece }\end{array}$ & $\begin{array}{c}\text { Arrivals } \\
\text { Abroad }\end{array}$ \\
\hline 1978 & 153330 & & 281469 & 231180 & & 665979 \\
\hline 1980 & 152482 & 5387 & 266170 & 386952 & & 810991 \\
\hline 1985 & 253494 & 31589 & 465721 & 734288 & 1884 & 1486976 \\
\hline 1990 & 155157 & 173770 & 298012 & 926820 & 1992 & 1555751 \\
\hline 1995 & 110777 & 334118 & 223649 & 1559204 & 1459 & 2229207 \\
\hline 2000 & 254231 & 450258 & 494317 & 20078233 & 799 & 21277838 \\
\hline 2005 & 193179 & 555647 & 448461 & 2003643 & 9032 & 3210003 \\
\hline 2006 & 212376 & 660904 & 493760 & 2159452 & 11109 & 3537601 \\
\hline 2007 & 248906 & 683669 & 537718 & 2162769 & 17666 & 3650728 \\
\hline 2008 & 254659 & 671477 & 547484 & 2154010 & 20000 & 3647635 \\
\hline 2009 & 280717 & 608693 & 553679 & 1952074 & 18916 & 3414079 \\
\hline
\end{tabular}


reach Crete every year, especially during the summer season. Specifically, in Heraklion airport more than 2,000,000 tourists arrive with international flights and in Chania airport more than 1,200,000 tourists arrive every year.

Tourist seasonality in Crete concentrates most of the tourist demand from May to October. Tourism industry of the island is trying to extend the season with the support of winter time charter flights.

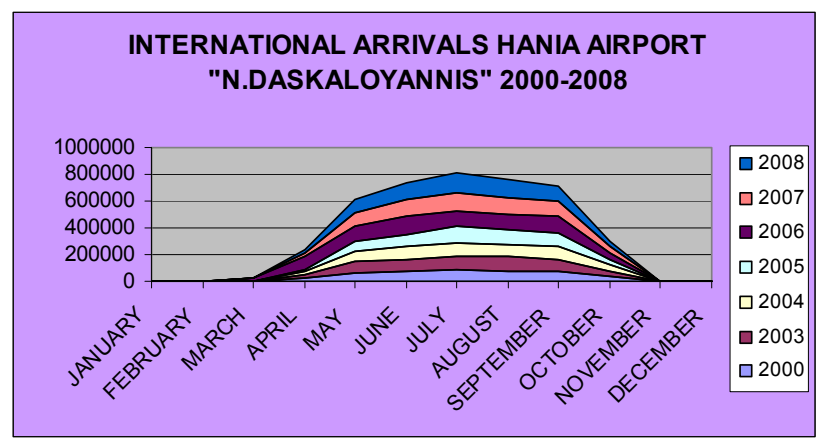

Figure 2: $\quad$ Arrivals in Chania Airport.

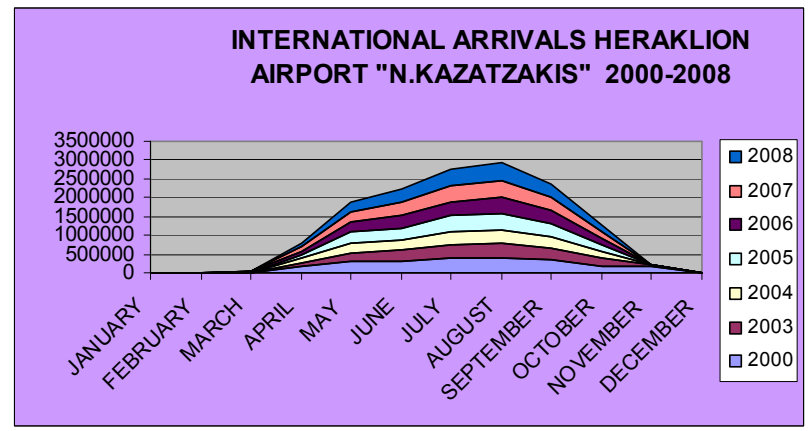

Figure 3: $\quad$ Arrivals in Heraclion Airport.

\section{Tourist supply}

Since the 1970s, mass tourism has provided Crete with increasing proportions of its GDP. Most of the physical development associated with package tourism has been concentrated on the northern coast east of Heraklion, Chania, Rethimno and Agios-Nikolaos [7]. Tourism in Crete has been as a development strategy, due to its potential for employment and income generation, infrastructural development and overall community [8]. Crete gathers more than 4 million tourists per year. Cretan tourist accommodation includes more than 200,000 beds in hotels, rooms to let, furnished apartments and traditional small hotels. 
Table 3: $\quad$ Tourism capacity in Crete.

\begin{tabular}{|c|c|c|c|c|c|}
\hline \multicolumn{6}{|c|}{ TOTAL TOURISM CAPACITY IN CRETE } \\
\hline & 2006 & 2010 & & 2006 & 2010 \\
\hline \multicolumn{3}{|c|}{ PREFECTURE OF HERAKLION } & \multicolumn{3}{|c|}{ PREFECTURE OF CHANIA } \\
\hline HERAKLION (town) & 2852 & 2646 & CHANIA (town) & 3353 & 3063 \\
\hline AGIA VARVARA & 0 & 0 & ACROTIRIOU & 1062 & 997 \\
\hline ARCALOHORI & 236 & 138 & AN.SELINOU & 19 & 52 \\
\hline ARCHANES & 65 & 103 & ARMENVN & 336 & 403 \\
\hline ASTTEROUSION & 151 & 13 & VAMOU & 511 & 606 \\
\hline VIANNOU & 125 & 22 & VOUKOLION & 63 & 158 \\
\hline GAZI & 10871 & 10916 & GEORGIOUPOLIS & 5403 & 5619 \\
\hline GOGROLAINI & 0 & 36 & EL VENIZELOU & 0 & 0 \\
\hline GORTYNAS & 101 & 79 & THERISOU & 63 & 56 \\
\hline GOUVES & 9929 & 9319 & INAHORIOU & 0 & 0 \\
\hline EPISKOPI & 0 & 0 & KANTANOU & 68 & 68 \\
\hline ZAROS & 186 & 170 & KERAMION & 0 & 0 \\
\hline THRAPSANOU & 0 & 0 & KISSAMOU & 892 & 1151 \\
\hline KASTELI & & 38 & KYLYMVARIOU & 1590 & 2128 \\
\hline KOFINA & 0 & 40 & KRYONERIDAS & 15 & 46 \\
\hline KROUSONAS & 180 & 0 & MOUSOURON & 101 & 101 \\
\hline MALIA & 11478 & 11408 & MYTHIMNIS & 147 & 108 \\
\hline MIRES & 97 & 59 & NEAS KYDONIAS & 10824 & 13295 \\
\hline NEA ALIKARNASOS & 631 & 248 & PELEKANOU & 605 & 580 \\
\hline NIKOU KAZATZAKI & 9 & 9 & PLATANIA & 8428 & 9610 \\
\hline ROUVA & & 0 & SOYDA & 99 & 110 \\
\hline TEMENOUS & & 0 & SFAKION & 339 & 353 \\
\hline TETRACHORIOU & 21 & 21 & FRE & 0 & 0 \\
\hline TYLISSOU & & 62 & ASI GVNIA & 0 & 0 \\
\hline CHERSONISOS & & 28235 & \multicolumn{3}{|c|}{ PREFECTURE OF RETHYMNO } \\
\hline \multicolumn{3}{|c|}{ PREFECTURE OF LASITHI } & RETHIMNO (town) & 13287 & 13420 \\
\hline AGIOS NIKOLAOS & 11954 & 12356 & ANOGIA & 50 & 50 \\
\hline IERAPETRA & 4037 & 4238 & ARKADIOU & 4933 & 7272 \\
\hline ITANOU & 239 & 275 & GEROPOTAMOU & 4933 & 5699 \\
\hline LAYKI & & 0 & KOYLOYKONA & 77 & 132 \\
\hline MAKRY GIALOS & 582 & 1195 & KOYRITON & 0 & 3 \\
\hline NEAPOLI & 30 & 30 & LAMBIS & 1472 & 1286 \\
\hline \multirow[t]{3}{*}{ OROPEDIO LASITIOU } & 97 & 102 & LAPPAION & 12 & 12 \\
\hline & & & NIKOFOROU FOKA & 304 & 335 \\
\hline & & & SYVRITOU & & \\
\hline \multirow[t]{2}{*}{ GAVDOS } & & 20 & FOINIKA & 1835 & 1950 \\
\hline & & & ZONIANA & & \\
\hline
\end{tabular}

Crete is one of the most popular holiday destinations in Greece. Fifteen percent of all arrivals in Greece come through the city of Heraklion (port and airport), while charter journeys to Heraklion last year made up $20 \%$ of all charter flights in Greece. Overall, more than two million tourists visited Crete last year, and this increase in tourism is reflected on the number of hotel beds, rising by $53 \%$ in the period between 1986 and 1991, when the rest of Greece saw increases of only $25 \%$. Today, the island's tourism infrastructure caters to all tastes, including a very wide range of accommodation; the island's facilities take in large luxury hotels with their complete facilities, swimming pools, sports and recreation, smaller family-owned apartments, camping facilities and others. 


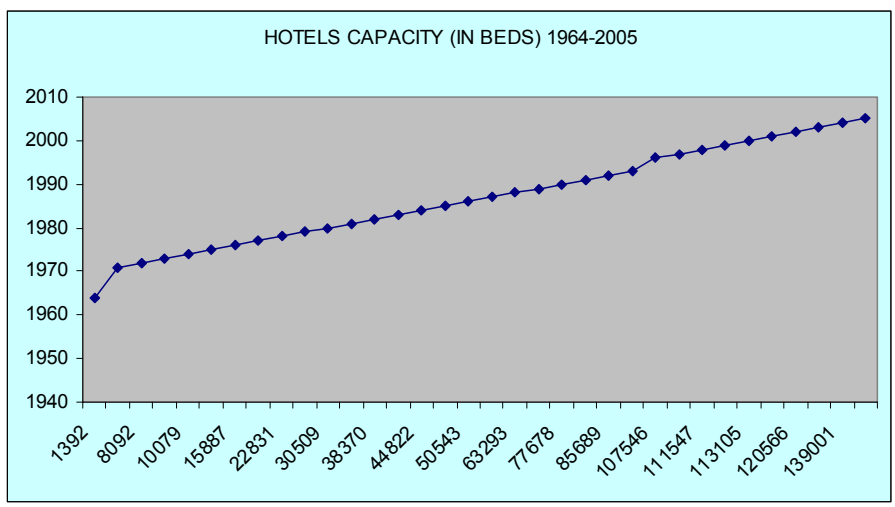

Figure 4: Hotel capacity history.

Today Crete has the infrastructure to offer its services even for athletic tourism. The combination of its numerous beaches and land will strong relief create an ideal environment [9] for the organizing of alternative tourism action, moreover, there are 69 diving centers.

Table 4: $\quad$ Alternative tourism enterprises, Crete [10].

\begin{tabular}{|c|c|c|c|}
\hline \multicolumn{4}{|c|}{ ALTERNATIVE TOURISM ENTERPRISES } \\
\hline HERACLION & LASITHI & CHANIA & RETHIMNO \\
\hline 11 & 3 & 4 & 8 \\
\hline
\end{tabular}

\section{Environmental indicators}

The coastline is where the land meets the sea or ocean [11]. Tourist development is adding to already existing pressures in coastal areas. Population densities are increasing in the tourist coastal regions during seasonal peaks [12, 13].

There are specific touristic areas that are in more favor of tourist attention, that are settled close to Hania, Rethimnon, Iraklion, Agios Nikolaos and Sitia, the most popular cities of Crete. These cities are situated across the north coast of the island of Crete.

Furthermore, across the southern coast line, with the view of Libian Sea, there are plenty of hotels, most of them situated nearby Ierapetra - Makri Yalos, Timbaki - Messara's bay, southern Rethimno, Sfakia, and the whole west coast line of Crete (Pelekanos and Inaschorio and Gramvousa area).

The coast and its adjacent areas on and off shore is an important part of a local ecosystem as the mixture of fresh water and salt water in estuaries provides many nutrients for marine life. Salt marshes and beaches also support a diversity of plants, animals, and insects crucial to the food chain. 


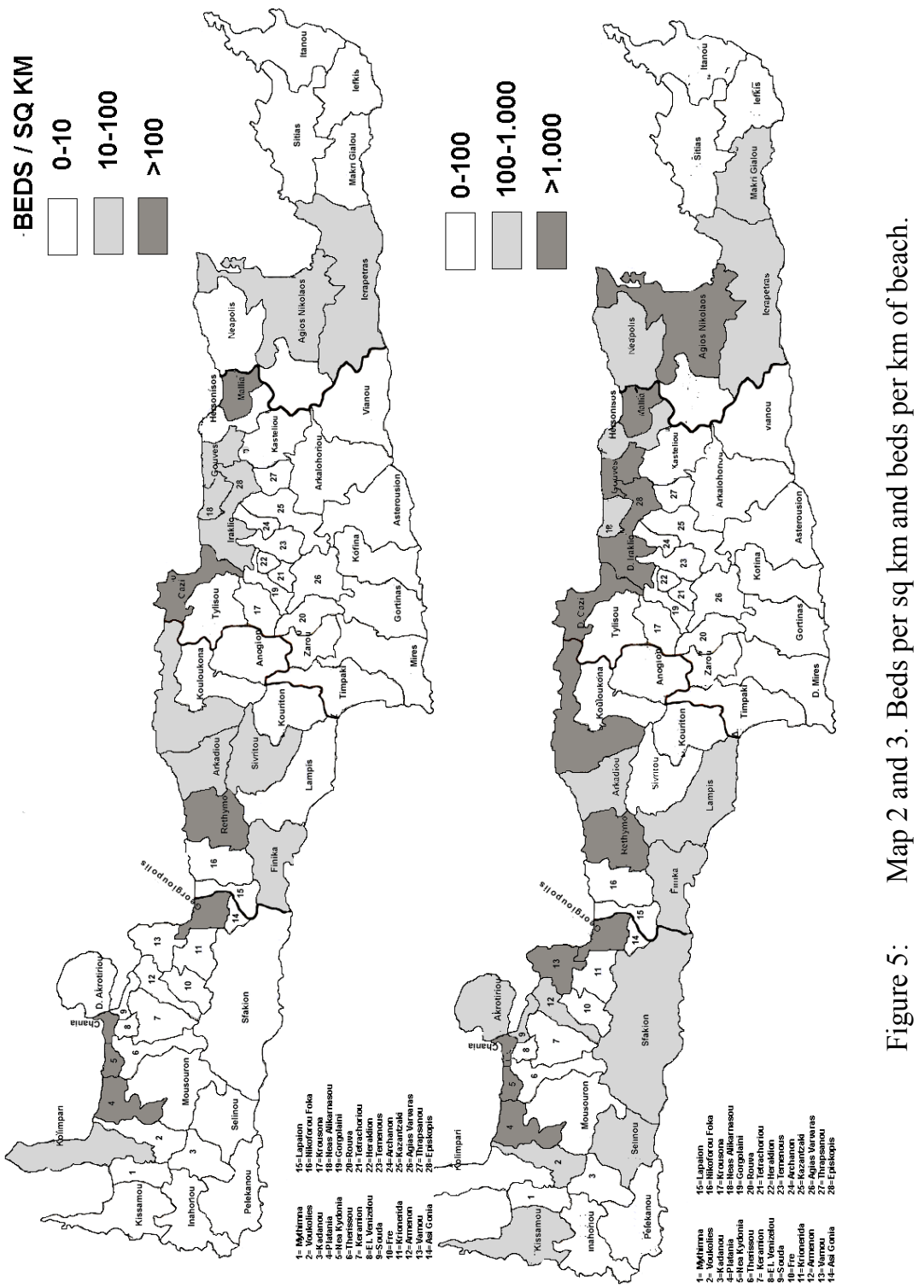


Table 5: $\quad$ Beach impact factor and beds per kilometers.

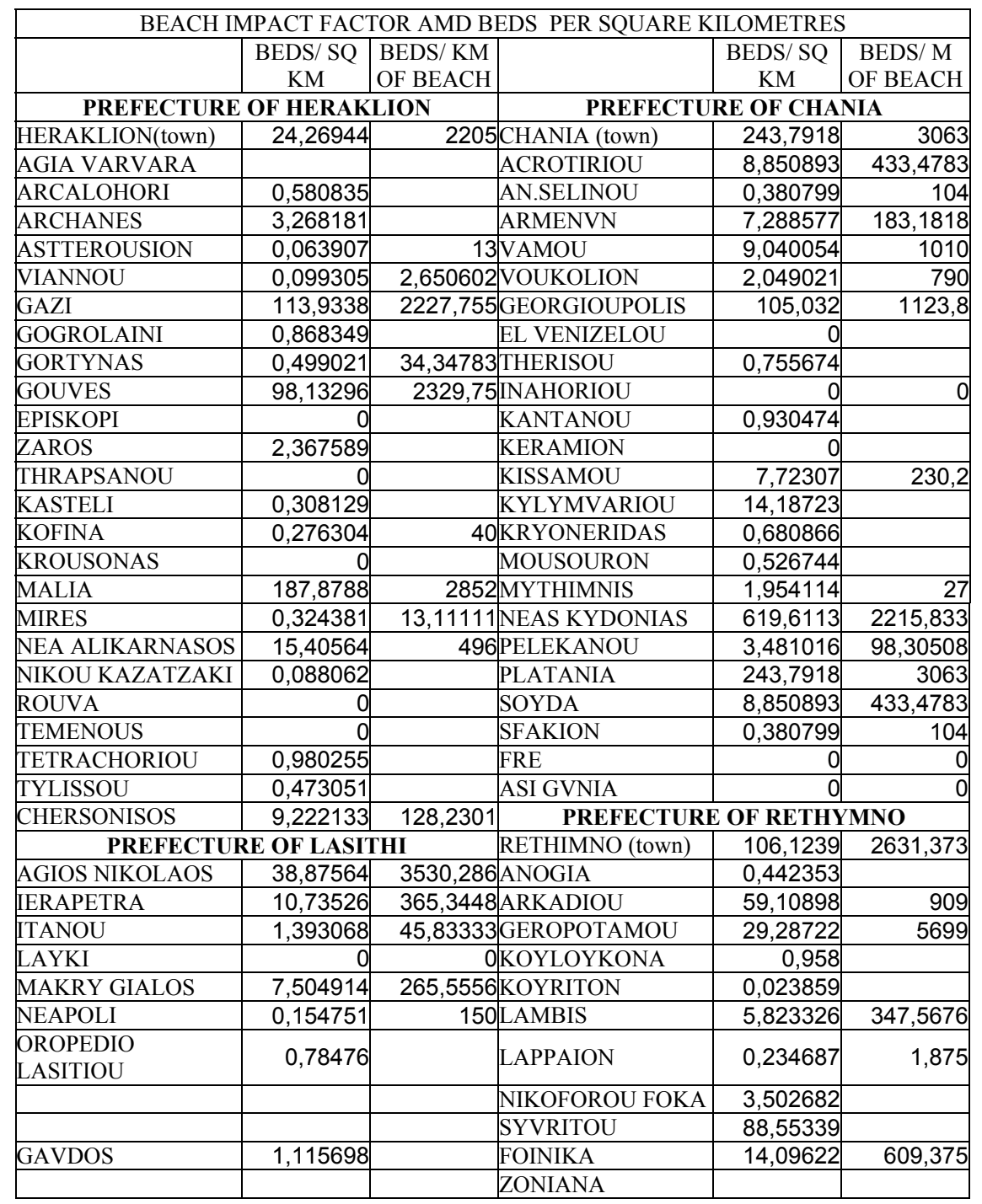

With this indicator we analyse the pressures facing the coastal environment, as they describe the concentration of people visiting and using the facilities of the coastal area, and especially beaches. From the data presented in Table 5, Gazi 2227, Gouves 2329, 75 with tourists per km as Platanias and Nea Kydonia 2215 and Rethimno 2631 as Agios Nicolaos 3530 and Geropotamos 5699 concentrates the most serious pressures at the coasts. 
Table 6: $\quad$ Shore and marine pollution in Heralcion [14].

\begin{tabular}{|c|c|c|c|c|c|}
\hline & $\begin{array}{c}\text { Illegal } \\
\text { buildings }\end{array}$ & $\begin{array}{c}\text { Hotels } \\
\text { (urban waste) }\end{array}$ & $\begin{array}{c}\text { Oil press } \\
\text { (residuals) }\end{array}$ & $\begin{array}{c}\text { Ships } \\
\text { (oil residuals) }\end{array}$ & $\begin{array}{c}\text { Urban } \\
\text { waste }\end{array}$ \\
\hline 1997 & 7 & 1 & 43 & 5 & \\
\hline 1998 & 4 & 2 & 25 & 1 & \\
\hline 1999 & 9 & 7 & 29 & 0 & \\
\hline 2000 & 8 & 15 & 19 & 7 & \\
\hline 2001 & 14 & 6 & 18 & 6 & \\
\hline 2002 & 8 & 12 & 22 & 4 & \\
\hline 2003 & 18 & 6 & 35 & 1 & \\
\hline 2004 & 14 & 9 & 11 & 5 & \\
\hline 2005 & 25 & 7 & 19 & 5 & \\
\hline 2006 & 9 & 5 & 19 & 2 & \\
\hline 2007 & 34 & 4 & 8 & 4 & 2 \\
\hline 2008 & 30 & 2 & 3 & 8 & 5 \\
\hline
\end{tabular}

Urban waste management (solid and liquid) on Crete is characterized by lack of efficiency regarding the waste treatment in the small cities and villages. Only the large urban centres fulfil the basic requirements of modern waste management installations. It is interesting to note that other smaller settlements do not even have a complete urban waste collection network.

Table 7: Waste management in Crete.

(UC $=$ under construction)

\begin{tabular}{|l|c|l|c|}
\hline \multicolumn{2}{|c|}{ PREFECTURE OF HERAKLION } & \multicolumn{2}{c|}{ PREFECTURE OF CHANIA } \\
\hline HERAKLION & $100 \%$ & CHANIA & $97 \%$ \\
\hline AGIA VARVARA & $\mathrm{UC}$ & AKROTIRIO & $\mathrm{NO}$ \\
\hline ARKAOLOCHORI & $\mathrm{NO}$ & ANATOLIKO SELINO & $\mathrm{UC}$ \\
\hline ARCHANES & $100 \%$ & ARMENON & $50 \%$ \\
\hline ASTTEROUSION & $\mathrm{NO}$ & VAMOY & $\mathrm{NO}$ \\
\hline VIANNOU & $\mathrm{UC}$ & VOUKOLION & $\mathrm{NO}$ \\
\hline GAZI & IS $\mathrm{WRKING}$ & GEORGIOUPOLI & $\mathrm{NO}$ \\
\hline GOGROLAINI & $\mathrm{UC}$ & ELEFTHRIOU & $\mathrm{NO}$ \\
\hline GORTYNAS & $\mathrm{NO}$ & TENIZELOY & $100 \%$ \\
\hline GOUVES & $\mathrm{UC}$ & INAHORIOU & $\mathrm{UC}$ \\
\hline EPISKOPI & $50-\%$ & KANTANOU & $\mathrm{UC}$ \\
\hline ZAROS & $\mathrm{NO}$ & KERAMION & $\mathrm{NO}$ \\
\hline THRAPSANOU & $80 \%$ & KISAMOU & $\mathrm{UC}$ \\
\hline KASTELI & $25 \%$ & KOLYMVARIOU & $70 \%$ \\
\hline KOFINA & $25 \%$ & KRYONERIDA & $\mathrm{UC}$ \\
\hline KROUSONAS & $\mathrm{NO}$ & MOUSOURON & $\mathrm{NO}$ \\
\hline MALIA & $\mathrm{ISORKING}$ & MYTHIMNIS & $\mathrm{NO}$ \\
\hline MIRES & $\mathrm{NO}$ & NEAS KYDONIAS & $100 \%$ \\
\hline NEA ALIKARNASOS & $80 \%$ & PELEKANOU & $\mathrm{NO}$ \\
\hline NIKOU KAZATZAKI & $100 \%$ & PLATANIA & $70 \%$ \\
\hline ROUVA & $\mathrm{NO}$ & SOUDA & $100 \%$ \\
\hline TEMENOUS & $\mathrm{NO}$ & SFAKION & $80 \%$ \\
\hline
\end{tabular}


186 Ecosystems and Sustainable Development VIII

Table 7: $\quad$ Continued.

(UC $=$ under construction $)$

\begin{tabular}{|l|c|l|c|}
\hline \multicolumn{2}{|c|}{ PREFECTURE OF HERAKLION } & \multicolumn{2}{c|}{ PREFECTURE OF CHANIA } \\
\hline TETRACHORIOU & UC & FRE & NO \\
\hline TYLISSOU & UC & ASI GONIA & NO \\
\hline TYMPAKI & $50 \%$ & GAVDOS ISLAND & $100 \%$ \\
\hline CHERSONISOS & $100 \%$ & \multicolumn{2}{c|}{ PREFECTURE OF RETHIMNO } \\
\hline \multicolumn{2}{|c|}{ PREFECTURE OF LASITHI } & RETHIMNO & $90 \%$ \\
\hline AGIOS NIKOLAOS & $90 \%$ & ANOGIA & $100 \%$ \\
\hline IERAPETRA & $75 \%$ & ARKADIOU & $90 \%$ \\
\hline ITANOU & $70 \%$ & GEROPOTAMOU & $\mathrm{UC}$ \\
\hline LAYKI & $45-50 \%$ & KOYLOYKONA & $\mathrm{NO}$ \\
\hline MAKRY GIALOS & $\mathrm{NO}$ & KOYRITON & $\mathrm{UC}$ \\
\hline NEAPOLI & $\mathrm{NO}$ & LAMBIS & NO \\
\hline OROPEDIO LASITIOU & $50 \%$ & LAPPAION & NO \\
\hline SITIA & $80 \%$ & NIKOFOROU FOKA & \\
\hline VRACHASI & $\mathrm{NO}$ & SYVRITOU & \\
\hline
\end{tabular}

Table 8: $\quad$ Shore and marine pollution in Agios Nicolaos [15].

\begin{tabular}{|c|c|c|c|c|}
\hline & Illegal buildings & $\begin{array}{c}\text { Oil press } \\
\text { (residuals) }\end{array}$ & $\begin{array}{c}\text { Ships } \\
\text { (oil residuals) }\end{array}$ & Urban waste \\
\hline 1998 & 7 & 1 & & \\
\hline 1999 & 5 & 3 & & \\
\hline 2000 & 4 & 1 & & \\
\hline 2001 & 16 & 4 & & \\
\hline 2002 & 1 & & & \\
\hline 2003 & 9 & & & \\
\hline 2004 & 10 & & & \\
\hline 2005 & & & & \\
\hline 2006 & 15 & 1 & & \\
\hline 2007 & 4 & & 1 & \\
\hline 2008 & 12 & & 1 & \\
\hline
\end{tabular}

Table 9: $\quad$ Shore and marine pollution in Rethimno [16].

\begin{tabular}{|c|c|c|c|c|}
\hline & Illegal buildings & $\begin{array}{c}\text { Oil press } \\
\text { (residuals) }\end{array}$ & $\begin{array}{c}\text { Ships } \\
\text { (oil residuals) }\end{array}$ & Urban waste \\
\hline 1998 & .2 & & & \\
\hline 1999 & & & & \\
\hline 2000 & & 1 & & \\
\hline 2001 & .6 & 6 & & .1 \\
\hline 2002 & 18 & 7 & & .1 \\
\hline 2003 & .4 & 2 & & 12 \\
\hline 2004 & .8 & & & .8 \\
\hline 2005 & 54 & 7 & & .2 \\
\hline 2006 & .4 & & & \\
\hline 2007 & .5 & & & \\
\hline
\end{tabular}




\section{Tourism impacts}

Impacts of tourism in coastal areas are: urban tourism enterprises, improper solid waste and garbage treatment, reduction of water resources, loss of free space in the towns,

Tourism can generate both positive and environmental impacts depending on how well development is planned and controlled. The principal impacts are outlined below [17]:

\subsection{Negative impacts}

Water pollution, air pollution, noise pollution, visual pollution, overcrowding and congestion, land use problems, environmental hazards, landslides, flooding and sedimentation of rivers, damage to historic and archaeological sites, improper waste disposal

\subsection{Positive impacts}

Conservation of important natural areas, conservation of important historic sites, improvement of environmental quality, enhancement of the environment, improvement of infrastructural, tourism carrying capacity assessment is the most important analytical technique to estimate the environmental pressures of uncontrollable tourist development.

\section{Proposals}

Tourist development indicators for Crete lead us to conclude that the tourist industry should aim at extending the tourist season to include more months, attain occupancy well over $50 \%$ for April, October, and probably more visitors with varied interests and expectations of the island.

Organization for the protection and development of environmentally sensitive areas. Due to the increased tourist demand, it is suggested that all the areas with environmental interests must be protected by a special organization [18] that, does not as yet exist now in Crete except the National Park of Samaria [19]. Natura 2000 Network areas are a step in the right direction, but must be supported with effective management schemes [20].

Extension of tourist services for the winter season months by developing and marketing novel tourist activities particular for the island (mountaineering, cultural events, conferences etc).

Completion of urban waste treatment plants and network, appropriate garbage handling (urban garbage treatment - olive oil press residuals management)

Restriction of illegal buildings at cities and coasts

Control of hotels' urban waste management systems

This concept of linking visitors with culture, nature and the environment in a harmonious way is not a new idea, but one that is now viewed on a global scale. Long-term, successful community involvement has preserved many popular rural 
tourist destinations such as the wine regions of Europe and the United States. Many rural communities have acted on instinct, rather than governmental directives or support, and usually with enough individual investment to achieve results [21].

Alternative tourist development.- Planning is conceptually related to sustainable development [22]. It includes approaches to deal with development and economic options, to prevent environmental damage and to involve public and stakeholders in decision-making processes. It is proposed that serious efforts have to be made in the direction of formulating viable policies and developing tools for effective implementation and control [23] as till now alternative tourism is not massively developed in Crete.

\section{Acknowledgements}

We would like to thank for their help and collaboration: Antonis Gialelakis, Neapoly, Lasithi-Crete, Dimitra Tselou and Maria Vasilaki economists, Spyros Gavanozis Hellenic Civil Aviation Authority, Greek national Tourist Organization - Heraclion Crete Branch as all the municipalities of the island.

\section{References}

[1] UNEP/MAP/PAP, 1997

[2] Coccosis $\mathrm{H}$ and Mexa A, 'The challenge of Tourism Carrying Capacity Assessment', Ashgate 2004

[3] Fernando J Garrigós Simón, Y. Narangajavana, and D. Palacios-Marqués. 'Carrying capacity in the tourism industry': a case study of Hengistbury Head'

[4] Zannou V, 'Guide of Socio-Economic Studies for the Integrated Management of the Water Environment' 1999

[5] http://en.wikipedia.org/wiki/Crete 11-12-10

[6] http://www.lonelyplanet.com/maps/europe/greece/crete/

[7] http://en.wikipedia.org/wiki/Crete 11-12-10

[8] Andriotis K., Local Authorities in Crete and the Development of TourismKiousis 1984

[9] Tsokas S. , "Region of Crete", Heraclion Crete Hotel Directory- Kalofolias publications 2005

[10] Cretan Union of Alternative Tourism

[11] The American Heritage Dictionary of the English Language: Fourth Edition. 2000. http://www.bartleby.com/61/43/C0434300.html. Retrieved 2008-12-11.

[12] Trumbic I, Tourism carrying Capacity assessment in the Mediterranean Coastal Tourist Destinations, 14 Biennial Coastal Zone Conference, New Orleans Louisiana, July 2005

[13] http://en.wikipedia.org/wiki/Coastal_zone\#cite_note-0 11-12-10

[14] Heraclion Central Port Authority - Hellenic Coast Guard

[15] Agios Nicolaos Port Authority - Hellenic Coast Guard 
[16] Rethimno Port Authority - Hellenic Coast Guard

[17] Lickorich L- Jenkins C, An introduction to Tourism, Butterworth Heinemann, Oxford 2000

[18] Prokopiou DG and Tselentis BS 'Proposals for sustainable development and Environmental protection for the island of Rhodes', Rhodes 2003 (in Greek)

[19] Papayanis T, 'Tourism carrying capacity in areas of ecological importance'

[20] Rose Nikki, Sustainable Tourism in Crete, excerpts from an article first printed in Stigmes Magazine, Crete

[21] Fidelis T., "Integrating environmental issues into the Portuguese planning system- 10 years of emerging challenges and persistent problems" Conference on sustainable planning and development Bologna 2005, Wessex Institute of Technology

[22] Prokopiou DG -Tselentis BS Bousbouras D. and Toanoglou M> "Environmental impacts caused by the tourist industry in Elafonisos Island and the Neapoli district, Greece" ECOSUD 2007,Sixth International Conference on Ecosystems and Sustainable Development, Organised by: Wessex Institute of Technology, UK -The University of Coimbra, PortugalThe University of Siena, 4-6 September 2007 Coimbra, Portugal 